\title{
Cetacean mortality due to interactions with fisheries and marine litter ingestion in the Croatian part of the Adriatic Sea from 1990 to 2019
}

\author{
Martina Đuras $^{1 *}$, Ana Galov², Kim Korpes ${ }^{1}$, Magdalena Kolenc1, Matea Baburić3 \\ Andrea Gudan Kurilj ${ }^{4}$, and Tomislav Gomerčićs
}

\author{
${ }^{1}$ Department of Anatomy, Histology and Embryology, Faculty of Veterinary Medicine, University of Zagreb, \\ Zagreb, Croatia \\ ${ }^{2}$ Division of Animal Physiology, Department of Biology, Faculty of Science, University of Zagreb, Zagreb, Croatia \\ ${ }^{3}$ Omiška 14, Zagreb, Croatia \\ ${ }^{4}$ Department of Veterinary Pathology, Faculty of Veterinary Medicine, University of Zagreb, Zagreb, Croatia \\ ${ }^{5}$ Department of Veterinary Biology, Faculty of Veterinary Medicine, University of Zagreb, Zagreb, Croatia
}

ĐURAS, M., A. GALOV, K. KORPES, M. KOLENC, M. BABURIĆ, A. GUDAN KURILJ, T. GOMERČIĆ: Cetacean mortality due to interactions with fisheries and marine litter ingestion in the Croatian part of the Adriatic Sea from 1990 to 2019. Vet. arhiv 91, 189-206, 2021.

\section{ABSTRACT}

Various anthropogenic threats negatively influence the survival of cetaceans in all world seas. Thanks to a longrunning marine mammal surveillance program, we are able to report the results of a detailed analysis of the influence of cetacean-fisheries interactions and marine litter ingestion on cetacean mortality in the Croatian part of the Adriatic Sea over the last three decades. The total number of dead cetaceans was 459, and included 334 bottlenose dolphins (Tursiops truncatus), 40 striped dolphins (Stenella coeruleoalba), ten Risso's dolphins (Grampus griseus), six Cuvier's beaked whales (Ziphius cavirostris) and four fin whales (Balaenoptera physalus). Three hundred of them were examined postmortally. Cetacean-fisheries interaction occurred frequently in the Adriatic Sea, being detected in 96 (20.9\%) of the recorded cases. Bycatch was the most abundant cetacean-fisheries interaction, with 66 (14.4\%) cases recorded. Good nutritional condition and evidence of recent feeding were the most common findings recorded in bycatch cases, followed by persistent froth in the airways, edematous lungs, bruises and an amputated fluke or tail. Cetacean-fisheries interactions other than bycatch affected 30 animals and included larynx strangulations, longterm tail entanglement and fishing gear in the stomach. Ingestion of marine litter that was not related to fisheries was recorded in four animals. This study reveals the considerable negative anthropogenic influence on cetaceans in the Adriatic Sea, especially the bottlenose dolphin that is considered to be the most numerous cetacean species therein, and demonstrates the need for the urgent development of a cetacean bycatch reduction program. Finally, it also shows the importance of sustaining national surveillance programs to gain scientifically based knowledge important for cetacean protection and prospects for their long-term survival.

Key words: bycatch; entanglement; fishing gear; marine litter; cetaceans; Adriatic Sea

\footnotetext{
*Corresponding author:

Assoc. Prof. Martina Đuras, PhD, DVM, Department of Anatomy, Histology and Embryology, Faculty of Veterinary Medicine University of Zagreb, Heinzelova 55, 10000 Zagreb, Croatia, Phone: +385 12390 252; E-mail: martina.duras@vef.hr
} 


\section{Introduction}

Human activities have had a negative influence on the survival of cetaceans in all the world's seas and oceans. Large whales were overexploited by commercial whaling, while hundreds of thousands of small cetaceans are killed incidentally in various fisheries each year. It was estimated that 2.9 million large whales were killed and processed by commercial whaling performed in the $20^{\text {th }}$ century (ROCHA et al., 2014). The most hunted species globally was the fin whale (Balaenoptera physalus) followed by the sperm whale (Physeter macrocephalus) (ROCHA et al., 2014). Nowadays, large whales are protected by the International Whaling Commission (IWC) through the moratorium on commercial whaling that has been in force since 1985 (ROCHA et al., 2014). However, small cetaceans are still endangered because of the incidental killing in fisheries known as bycatch (BROWNELL JR et al., 1989). Bycatch is defined as the catch of a non-target or noncommercial species in fishing gear (PELTIER et al., 2016) and is considered part of the capture of individuals that are discarded, dead or injured to an extent that they die in the end (HALL, 1996). It threatens some of the most vulnerable small cetaceans that are listed as Critically Endangered by the International Union for Conservation of Nature (IUCN) Red List (BROWNELL et al., 2019). Bycatch in gillnets contributed to the almost certain extinction of the Baiji (Lipotes vexillifer), a small cetacean species that was endemic to the Yangtze River (BROWNELL et al., 2019). The number of cetaceans that die in fishing nets per year is enormous. The latest estimate of cetacean bycatch in the Indian Ocean tuna gillnet fisheries shows that 80,000 cetaceans per year die entangled in the nets of this type of fishery (ANDERSON et al., 2019). When expressed as the cetacean bycatch rate, it may be in the range of 175 cetaceans per 1,000 t of tuna. The cumulative cetacean bycatch for tuna gillnet fisheries in the Indian Ocean was estimated to be at an astonishing level of 4.1 million dolphins during the period from 1950 to 2018 (ANDERSON et al., 2019).

Cetaceans in European waters are also highly impacted by fishing (PELTIER et al., 2016).
Dolphins that had died because of bycatch were reported in the waters around UK (BAKER, 1992; KUIKEN et al., 1994; BAKER, 1996; KUIKEN et al., 1996; GARCÍA HARTMANN et al., 1996; LEENEY et al., 2008), the Baltic and the North Sea (SIEBERT et al., 1996), the Atlantic waters off the coast of the Netherlands and France (GARCÍA HARTMANN et al., 1996), in the Black Sea (BIRKUN, 1996), Thracian Sea (Greece) (MILANI et al., 2019), the Adriatic Sea (Italian part) (FORTUNA et al., 2010) and other Mediterranean regions (FAO, 2020). It is estimated that 3,650 to 4,700 common dolphins (Delphinus delphis) die in fishing nets per year as bycatch in the Bay of Biscay (PELTIER et al., 2016).

Levels of bycatch can be assessed by postmortem examination of cetaceans, conducted as a part of national marine mammal surveillance programs. Postmortem examinations include necropsies of carcasses that are found floating in the sea or are washed up on the shore. Some of these may die as bycatch but are lost out of the net or discarded at sea by fishermen. The death of a cetacean incidentally captured in a fishing net is caused by trauma and/or lack of oxygen. The lack of oxygen is the result of entanglement and forced submersion. It causes the failure of pulmonary gas exchange due to the accumulation of proteinaceous fluid and haemorrhage within the alveolar spaces and interstitium, distension of the alveoli, rupture of the alveolar walls and myosphincters of the bronchiole, and compression of pulmonary capillaries (KNIERIEM and GARCÍA HARTMANN, 2001). However, the diagnosis of forced submersion due to the bycatch can be very difficult. As there are no pathognomonic lesions (DE QUIRÓS et al., 2018), many lesions associated with bycatch may also have other causes. On the other hand, bycatch lesions can be masked by postmortal autolysis (KUIKEN, 1996). Consequently, it is rarely possible to diagnose bycatch with certainty when dolphins are not directly found entrapped in a net. At best, it can typically be concluded that the findings are consistent with bycatch (KUIKEN, 1996). KUIKEN (1996) lists criteria for enhancing bycatch diagnosis, but highlights the fact that these 
criteria are not based on scientific research but on general experience gained by carrying out cetacean necropsies. Nevertheless, the more bycatch criteria occur together, the more certain the diagnosis becomes (GARCÍA HARTMANN et al., 1996). All the findings and lesions that may be observed in carcasses affected by bycatch are referred to the term "peracute underwater entrapment syndrome" (DE QUIRÓS et al., 2018).

A new rising threat to cetaceans is marine litter. Solid materials such as wood, plastic, metal, glass, rubber and textile are considered marine litter, with plastic being the most dominant (CÓZAR et al., 2014). The Mediterranean Sea is a huge accumulation zone of plastic debris (LAMBERT et al., 2020) with a surface load of one thousand tons (COZAR et al., 2015). Whales may ingest plastic for several reasons. They may mistake plastic for their prey, accidentally ingest plastic when it is close to their prey, or try to catch it out of curiosity, especially juveniles, which results in swallowing an item (LAIST, 1987; WALKER and COE, 1990). Ingested plastics leads to gastrointestinal disorders such as impacted stomach, digested blood in the stomach and ulcerative gastritis. Cetaceans with foreign bodies in their gastrointestinal tract, such as plastic bags, also have poor body condition (PUIGLOZANO et al., 2018).

The Adriatic Sea is a semi-closed sea in the eastern Mediterranean basin which, as regards marine mammals, is nowadays inhabited only by a population of bottlenose dolphins (Tursiops truncatus). In the past, the common dolphin (Delphinus delphis) (BRUSINA, 1889; BEARZI et al., 2004) and the Mediterranean monk seal (Monachus monachus) were also regular marine mammal inhabitants (BRUSINA, 1889). The regionally extirpated Mediterranean monk seal has been re-sighted on several occasions (GOMERČIĆ et al., 2011), while sightings of common dolphins are extremely rare (BEARZI and NOTARBARTOLO DI SCIARA, 1995; GENOV et al. 2020). The bottlenose dolphin in the Croatian part of the Adriatic Sea is of a single morphological type (ĐURAS et al., 2014). Genetic analyses did not indicate population genetic structuring and reduction of their genetic diversity (GALOV et al., 2011). However, some signals of fine scale population division were detected within the Adriatic Sea, although the pattern of population structuring remains unclear in the basin (GASPARI et al., 2015). National Protocol for reporting injured/sick or dead protected sea animals (sea turtles, sea mammals, sharks) (http://www.haop.hr/ $\mathrm{hr} /$ tematska-podrucja/prirodne-vrijednosti-stanje-iocuvanje/ukljucite-se-u-zastitu/protokoli-za-0) was established in Croatia in order to detect threats to all endangered marine species and to manage them successfully. The protocol is run by the Department for the Environment and Nature, which works under the jurisdiction of the Croatian Ministry of Environmental Protection and Energy.

Various fatal human impacts on cetaceans have previously been recorded in the Adriatic Sea. Culling campaigns occurred between the second half of the $18^{\text {th }}$ century and the 1960 s (CRNKOVIĆ, 2001; BEARZI etal., 2004). Cetacean bycatch was reported during Italian pelagic trawler fishing (FORTUNA et al., 2010). Cases of larynx strangulations with fishing net particles were described as fatal dolphin - gill net fishery interactions (ĐURAS GOMERČIĆ et al., 2009). Plastic marine litter was ingested by a solitary Cuvier's beaked whale that was monitored for over a month in the southern part of the Adriatic Sea (GOMERČIĆ et al., 2006). However, there has been no detailed analysis of the influence of fishery related factors and marine litter on cetacean survival in the Adriatic Sea. This study reports the prevalence of bycatch and other cetacean-fisheries interactions and marine litter ingestion in cetaceans that were found dead in the Croatian part of the Adriatic Sea over the last three decades. The data should be used for future conservation activities, with the goal of preserving whales in the Adriatic Sea.

\section{Materials and methods}

Records on cetaceans found dead from 1990 to 2019 in the Croatian part of the Adriatic Sea were reviewed and analysed for the purpose of this study. These records, which include photographs, the findings of postmortem examinations performed according to a standard protocol (based on KUIKEN and GARCÍA HARTMANN, 1991), tissue samples and skeletons, are part of a marine mammal collection kept at the Faculty of Veterinary 
Medicine, University of Zagreb in Zagreb, Croatia. The collection was established within the marine mammal surveillance program that has been in place since 1990. General data and necropsy findings were surveyed.

Out of all the recorded cases we selected cases with findings related to fisheries interactions and ingested marine litter. We classified the fisheries related findings in three categories: known bycatch, suspected bycatch and cetacean - fisheries interactions other than bycatch.

Individuals that were found entrapped in fishing gear were categorized as known bycatch.

Dolphins that were found dead, either stranded on the coast or floating in the sea, in which bycatch associated lesions were observed during postmortem examination, were categorized as suspected bycatch. Postmortem findings in suspected bycatch cases were assessed by the following criteria for the diagnosis of bycatch (Table 1) modified from KUIKEN (1996): 1) exclusion of other causes of death, 2) good nutritional condition, 3) evidence of recent feeding, 4) superficial skin lesions, 5) bruises, 6) skull fractures and broken teeth, 7) oedematous lungs, 8) persistent froth in the airways, 9) an amputated fluke or tail and 10) penetrating incision into the body cavity. We also reported findings based on these criteria for known bycatch cases (individuals entrapped in fishing gear).

Cases of cetacean-fisheries interactions that were not considered bycatch, because they did not result in the immediate death of an animal, were categorized on the basis of any of the following findings: larynx strangulation, long-term tail entanglement and fishing gear in the stomach.

Cases of ingested marine litter were confirmed by the presence of marine litter in the gastrointestinal tract, found during postmortem examinations.

All recorded dead cetaceans were divided into three age groups: calves, juveniles and adults (modified according to BEARZI et al. (1997) and ESTEBAN et al. (2016). Specimens below and

Table 1. Criteria for the diagnosis of bycatch modified from Kuiken (1996)

\begin{tabular}{|c|c|}
\hline Criterion & Explanation \\
\hline 1 - Exclusion of other causes of death & Examination of all organ systems must be carried out. \\
\hline 2 - Good nutritional condition & $\begin{array}{l}\text { Indicates that the dolphin was not suffering from severe chronic diseases } \\
\text { or from starvation. }\end{array}$ \\
\hline 3 - Evidence of recent feeding & The individual was healthy enough to catch prey shortly before it died. \\
\hline 4 - Superficial skin lesions & $\begin{array}{l}\text { Cuts in the edge of mouth, fin or tail caused by fishing net wherever it is } \\
\text { in contact with skin and is under high tension. The cuts may vary in } \\
\text { depth and are usually straight. Blood may be seeping from the wound } \\
\text { and haemorrhage may be in the surrounding tissue but there is no } \\
\text { inflammatory reaction. }\end{array}$ \\
\hline 5 - Bruises & $\begin{array}{l}\text { Haemorrhage in the subcutaneous tissue between the blubber layer and } \\
\text { the muscle and they may occur when the dolphin is trapped under } \\
\text { water or is being hauled up onto the fishing vessel. }\end{array}$ \\
\hline 6 - Skull fractures and broken teeth & $\begin{array}{l}\text { Appear due to trauma when the fishing net is being hauled aboard or } \\
\text { the dolphin is dropped on deck. The fracture is surrounded by } \\
\text { haemorrhage. }\end{array}$ \\
\hline 7 - Oedematous lungs & $\begin{array}{c}\text { Are the result of hypoxia and loss of membrane integrity in the lung } \\
\text { tissue that is followed by the leak of proteinaceous fluid mixed with } \\
\text { erythrocytes into the alveoli. }\end{array}$ \\
\hline 8 - Persistent froth & Appears due to the proteinaceous fluid whipped into the airways. \\
\hline 9 - Amputated fluke or tail & $\begin{array}{c}\text { Fluke or tail are amputated during the release of a cetacean carcass from a } \\
\text { fishing net. }\end{array}$ \\
\hline $\begin{array}{l}10 \text { - Penetrating postmortal incision } \\
\text { into body cavity. }\end{array}$ & Are made by fishermen to make the carcass sink. \\
\hline
\end{tabular}


about one-half of adult length were classified as calves. Juveniles were those that were about twothirds of adult length and still physically immature, and adults were physically mature animals.

Physical maturity for the bottlenose dolphin was established according to the growth curve published in ĐURAS et al. (2016), while for other cetacean species, it was based on the respective published adult lengths (RICE, 1998).

\section{Results}

Dead cetacean records (1990 - 2019). From 1990 to 2019 a total of 459 dead cetaceans were recorded along the Croatian part of the Adriatic Sea (Table 2), with a mean of 15.3 cases annually. No geographical clustering of cetacean strandings was apparent (Fig. 1) and there were no mass mortalities. The most common species was the bottlenose dolphin $(\mathrm{n}=334,72.8 \%)$, followed by the striped dolphin (Stenella coeruleoalba) $(\mathrm{n}=40,8.7 \%)$, the Risso's dolphin (Grampus griseus) $(\mathrm{n}=10,2.2 \%)$, the Cuvier's beaked whale (Ziphius cavirostris) $(\mathrm{n}=6,1.3 \%)$ and the fin whale (Balaenoptera physalus) $(\mathrm{n}=4,0.9 \%)$. In $14.2 \%(\mathrm{n}=65)$ of the cases the cetacean species was not determined due to inaccessible carcass and/or lack of high-quality photos, videos, or a reliable or an efficient carcass description.

Out of the total number of recorded dead cetaceans, $65.4 \%(\mathrm{n}=300)$ were examined postmortally. Postmortem examination of $34.6 \%$ $(\mathrm{n}=159)$ reported cetacean carcasses was not possible due to various reasons, e.g. a location hard to access, late notification of the carcass resulting in heavy carcass decomposition, bad weather conditions, no local support to load the carcass, or insufficient funding. In total, 96 cases of cetaceanfisheries interactions were recorded (66 bycatch and 30 cetacean-fishery interactions other than bycatch) (Tables 2 and 3), which makes $20.9 \%$ of the recorded carcasses or $32 \%$ of those examined postmortem.

\section{Bycatch}

Known bycatch. A cetacean found entrapped in a fishing net, i.e. known bycatch, was recorded 21 times (Table 3$)(4.6 \%$ out of all records, $n=459)$. In 19 cases the entrapped species was a bottlenose dolphin and one individual found entrapped was a Risso's dolphin. The species, age class and sex of one entrapped dolphin could not be determined due to the lack of recorded data. The entrapment was in a gill net in 17 cases, in a trawler net in two cases, and in two cases the net type was unknown. Ten out of 19 bottlenose dolphins found entrapped in a fishing net were calves (52.6\%), four of which had milk remains in their stomach. The remaining four bottlenose dolphins were juveniles and five were adults. The sex ratio was nearly equal: nine females, eight males and two of unknown sex. The entrapped Risso's dolphin was an adult male.

A postmortem examination was performed on 14 of the recorded known bycatches, 13 bottlenose dolphins and one Risso's dolphin (Table 3). All the examined individuals were in good nutritional

Table 2. Records of dead cetaceans from 1990 until 2019 in the Croatian part of the Adriatic Sea.

\begin{tabular}{|l|c|c|c|c|c|}
\hline Species & $\begin{array}{c}\text { Recorded } \\
\text { cases }\end{array}$ & $\begin{array}{c}\text { Postmortally } \\
\text { examined }\end{array}$ & Bycatch & $\begin{array}{c}\text { Cetacean -fisheries } \\
\text { interactions other } \\
\text { than bycatch }\end{array}$ & Ingested marine litter \\
\hline Tursiops truncatus & 334 & 253 & 61 & 30 & 2 \\
\hline Stenella coeruleoalba & 40 & 33 & 3 & 0 & 1 \\
\hline Grampus griseus & 10 & 8 & 1 & 0 & 0 \\
\hline Ziphius cavirostris & 6 & 4 & 0 & 0 & 1 \\
\hline Balaenoptera physalus & 4 & 2 & 0 & 0 & 0 \\
\hline unknown & 65 & 0 & 1 & 0 & 4 \\
\hline Total & 459 & 300 & 66 & 30 & 0 \\
\hline
\end{tabular}




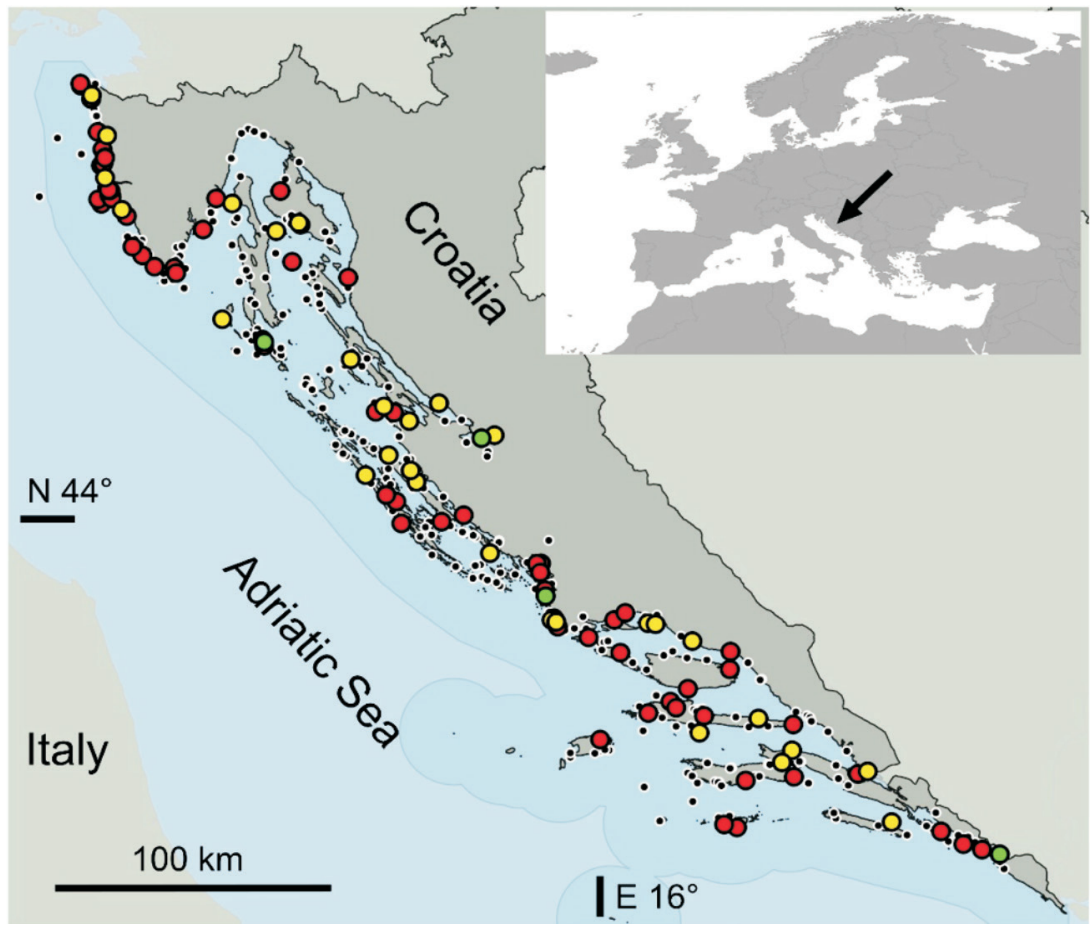

Fig. 1. Spatial distribution of cetacean carcasses recorded from 1990 to 2019 in the Croatian part of the Adriatic Sea (red: bycatch cases, yellow: cases associated with cetacean - fisheries interactions other than bycatch, green: cases of ingested marine litter not associated with cetacean - fisheries interactions, black (smaller dots): all other cetacean findings).

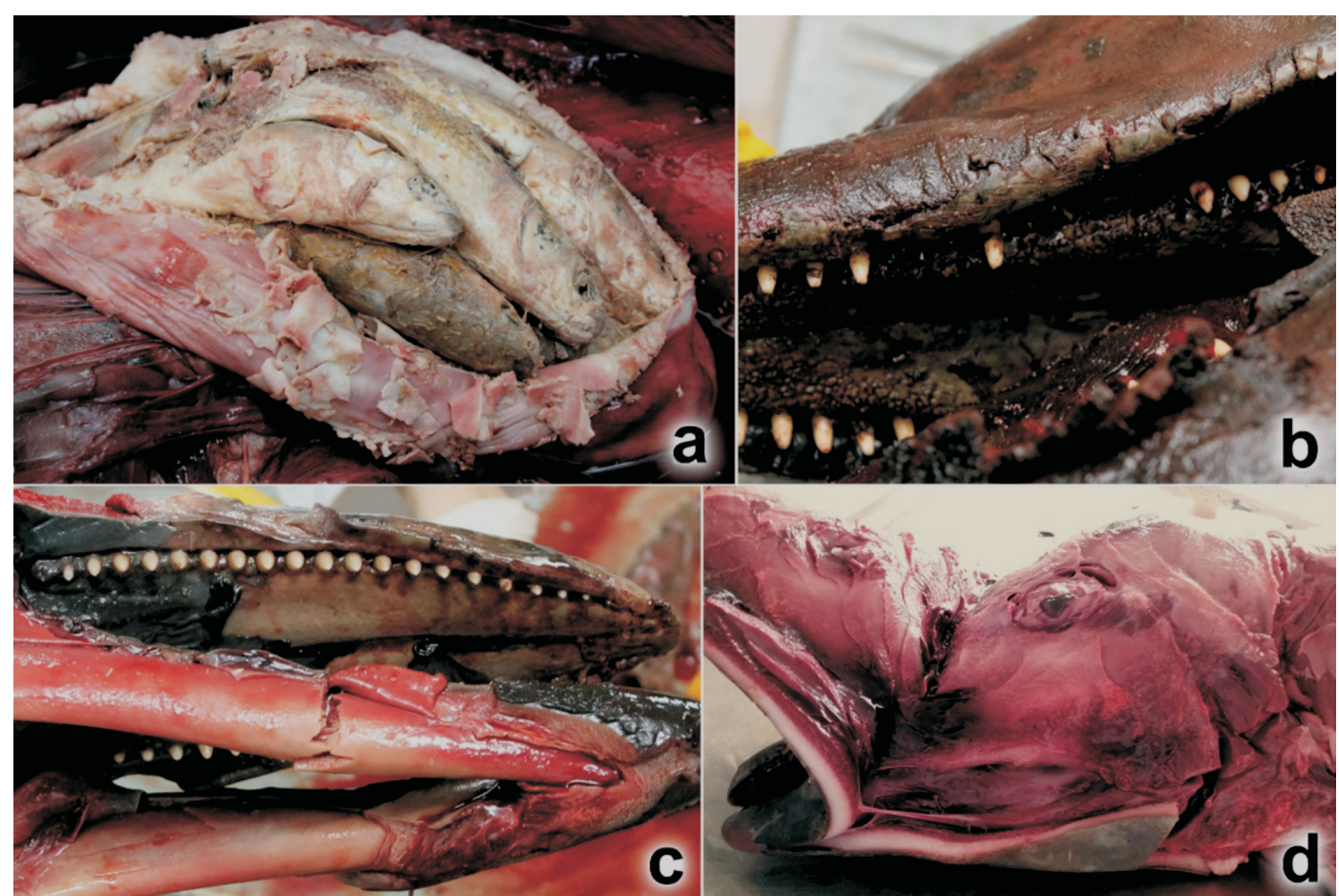

Fig. 2. Bycatch associated lesions: a) evidence of recent feeding (dolphin ID 305), b) broken teeth (dolphin ID 321),

c) jaw fractures (dolphin ID 338) and d) bruises in the subcutis of the intermandibular region (dolphin ID 417).

Criteria for the diagnosis of bycatch are modified from Kuiken (1996) (Table 1). 
M. Đuras et al.: Cetacean mortality (fisheries interactions and marine litter ingestion) in the Croatian part of the Adriatic Sea from 1990 to 2019

Table 3. Cetacean-fisheries interactions form the Croatian part of the Adriatic Sea - number of cases following the criteria for the diagnosis of bycatch as modified from Kuiken (1996) (Table 1).

\begin{tabular}{|c|c|c|c|c|c|c|}
\hline & $\begin{array}{l}\text { Tursiops } \\
\text { truncatus }\end{array}$ & $\begin{array}{c}\text { Stenella } \\
\text { coeruleoalba }\end{array}$ & $\begin{array}{l}\text { Grampus } \\
\text { griseus }\end{array}$ & Unknown & Total & $\begin{array}{l}\text { Frequency of } \\
\text { criteria found in }\end{array}$ \\
\hline Known bycatch & 19 & & 1 & 1 & 21 & \\
\hline $\begin{array}{l}\text { Postmortally examined known } \\
\text { bycatch }\end{array}$ & 13 & & 1 & & 14 & $\begin{array}{l}14 \text { known } \\
\text { bycatch cases }\end{array}$ \\
\hline $\begin{array}{l}\text { Criterion 2): Good nutritional } \\
\text { condition }\end{array}$ & 13 & & 1 & & & $100 \%$ \\
\hline $\begin{array}{l}\text { Criterion 3): Evidence of recent } \\
\text { feeding }\end{array}$ & 11 & & 1 & & & $85.7 \%$ \\
\hline $\begin{array}{l}\text { Criterion 4). Superficial skin } \\
\text { lesions }\end{array}$ & 1 & & & & & $7.1 \%$ \\
\hline Criterion 7): Edematous lungs & 4 & & 1 & & & $35.7 \%$ \\
\hline $\begin{array}{l}\text { Criterion 8): Persistent froth in the } \\
\text { airways }\end{array}$ & 5 & & 1 & & & $42.9 \%$ \\
\hline $\begin{array}{l}\text { Criterion 9): Amputated fluke or } \\
\text { tail }\end{array}$ & 3 & & & & & $21.4 \%$ \\
\hline $\begin{array}{l}\text { Criterion 10): Penetrating incision } \\
\text { into body cavity }\end{array}$ & 1 & & & & & $7.1 \%$ \\
\hline $\begin{array}{l}\text { Suspected bycatch (all } \\
\text { postmortally examined) }\end{array}$ & 42 & 3 & & & 45 & $\begin{array}{l}45 \text { suspected } \\
\text { bycatch cases }\end{array}$ \\
\hline $\begin{array}{l}\text { Criterion 2): Good nutritional } \\
\text { condition }\end{array}$ & 40 & 3 & & & & $95.6 \%$ \\
\hline $\begin{array}{l}\text { Criterion 3): Evidence of recent } \\
\text { feeding }\end{array}$ & 37 & 2 & & & & $86.7 \%$ \\
\hline Criterion 5): Bruises (on the head) & 15 & & & & & $33.3 \%$ \\
\hline $\begin{array}{l}\text { Criterion 6): Skull fracture and } \\
\text { broken teeth }\end{array}$ & 3 & & & & & $6.7 \%$ \\
\hline Criterion 7): Edematous lungs & 18 & & & & & $40.0 \%$ \\
\hline $\begin{array}{l}\text { Criterion 8): Persistent froth in the } \\
\text { airways }\end{array}$ & 19 & & & & & $42.2 \%$ \\
\hline $\begin{array}{l}\text { Criterion 9): Amputated fluke or } \\
\text { tail }\end{array}$ & 12 & 2 & & & & $31.1 \%$ \\
\hline $\begin{array}{l}\text { Criterion 10): Penetrating incision } \\
\text { into body cavity }\end{array}$ & 5 & 1 & & & & $13.3 \%$ \\
\hline $\begin{array}{l}\text { Additional findings: long- term } \\
\text { tail entanglement and/or fishing } \\
\text { gear in the stomach }\end{array}$ & 3 & & & & & \\
\hline Bycatch - total & 61 & 3 & 1 & 1 & 66 & \\
\hline $\begin{array}{l}\text { Cetacean-fisheries interactions } \\
\text { other than bycatch }\end{array}$ & 30 & & & & 30 & \\
\hline Larynx strangulations & 16 & & & & & \\
\hline Long-term tail entanglement & 2 & & & & & \\
\hline Fishing gear in the stomach & 19 & & & & & \\
\hline
\end{tabular}


condition (criterion 2). Twelve had food remains in the stomach (criterion 3). Superficial skin lesions (criterion 4) caused by net entanglement were observed in one dolphin. Oedematous lungs (criterion 7) were found in five dolphins and persistent froth (criterion 8) in the airways of six dolphins. The tail and fluke were cut off (criterion 9) in three dolphins, and one of them had a penetrating postmortal incision into the body cavity (criterion 10, Fig. 3c). Three dolphins were found with body parts entangled in the net (the head - dolphin ID 70, the tail - ID 166, the whole body - ID 131).

Suspected bycatch. In 45 cases suspected bycatch was determined based on the presence of bycatch associated lesions that were observed during necropsy (Table 3). Suspected bycatch was determined in 42 bottlenose dolphins and three striped dolphins. In these dolphins a cause of death other than bycatch was excluded, which is in concordance with criterion 1 for the diagnosis of bycatch modified from KUIKEN (1996) (see Material and Methods). Suspected bycatch was determined in 16 female and 26 male bottlenose dolphins. Out of these, three female bottlenose dolphins were adults, eight were juveniles and five calves, while 17 males were adults, eight juveniles, and one was a calf. Suspected bycatch was determined in one male and two female striped dolphins. The male striped dolphin was a juvenile, as was one female, while the other female was an adult.

Bycatch associated lesions. All suspected bycaught dolphins $(\mathrm{n}=45)$ had multiple bycatch associated lesions (Table 3). As many as $95.6 \%$ (43 out of 45) of the suspected bycaught dolphins were in good nutritional condition (criterion 2) and $86.7 \%(\mathrm{n}=39)$ had been eating prior to death (criterion 3, Fig. 2a). Bruises (criterion 5; Fig. 2d) in the subcutis of the intermandibular space, dorsal rostrum and the melon were found in $33.3 \%$ (n $=15$ ) dolphins. Skull fractures and broken teeth (criterion 6, Fig. 2b and 2c) were observed in 6.7\% $(\mathrm{n}=3)$ dolphins. Oedematous lungs (criterion 7) were found in $40.0 \%(n=18)$ dolphins. Such lungs were voluminous with dark and light red areas (Fig. $3 b)$. The fluid accumulated in the lungs appeared as persistent froth (criterion 8, Fig. 3a) in the airways in $42.2 \%(n=19)$ dolphins. The froth was white, light yellowish or dark red. The fluke, tail or dorsal fin were cut off (criterion 9, Fig. 3c) in $31.1 \%$ ( $n=$ 14) dolphins. The amputations were straight with no haemorrhage or swelling of the surrounding tissue. Penetrating postmortal incisions into body cavities (criterion 10, Fig. 3c) were observed in $13.3 \%(n=$ 6) cases. Such incisions were also straight with no signs of inflammation or haemorrhage around them.

In all known bycatch cases one or multiple bycatch associated lesions were also found, with good nutritional condition and evidence of recent feeding again being the most prevalent $(100 \%$ and $85.7 \%$ of known bycatch cases, respectively) (Table 3).

Total bycatch. To express the total bycatch in the Croatian part of the Adriatic Sea the dolphins found entrapped in fishing nets - known bycatches, and dolphins categorized as suspected bycatches, were combined (Table 3). The total bycatch prevalence between 1990 and 2019 in the Croatian part of the Adriatic Sea was $14.4 \%(n=66$, i.e. 21 known and 45 suspected bycatches out of 459 reported cases) (Tables 2 and 3 ) or $19.7 \%$ when only postmortally examined cases are analysed $(\mathrm{n}=59$, i.e. 14 known and 45 suspected bycatches out of 300 examined cases) (Table 3 ). The species affected by bycatch were the bottlenose dolphin, striped dolphin and Risso's dolphin.

In the bottlenose dolphin, $18.3 \%$ of recorded cases (61 out of 334) or $21.7 \%$ if expressed as examined cases (55 out of 253) were affected by bycatch (Tables 2 and 3). Among the bycaught bottlenose dolphins, calves represented 26.2\% (16 out of 61 ), juveniles $32.8 \%$ (20 out of 61 ) and adults $41.0 \%$ ( 25 out of 61 ). Furthermore, three striped dolphins were affected by bycatch (two juveniles and one adult) and one adult Risso's dolphin.

Good nutritional condition and evidence of recent feeding were the most common findings in bycaught cetacean. Good nutritional condition was recorded in $96.6 \%$ (57 cases) and evidence of recent feeding was found in $86.4 \%$ cases (51 out of 59 examined bycaught dolphins).

Cetacean-fisheries interactions other than bycatch. Other findings that were associated with cetacean-fisheries interactions but did not result in the immediate death of the entrapped animal and, thus, were not considered cases of bycatch were: 


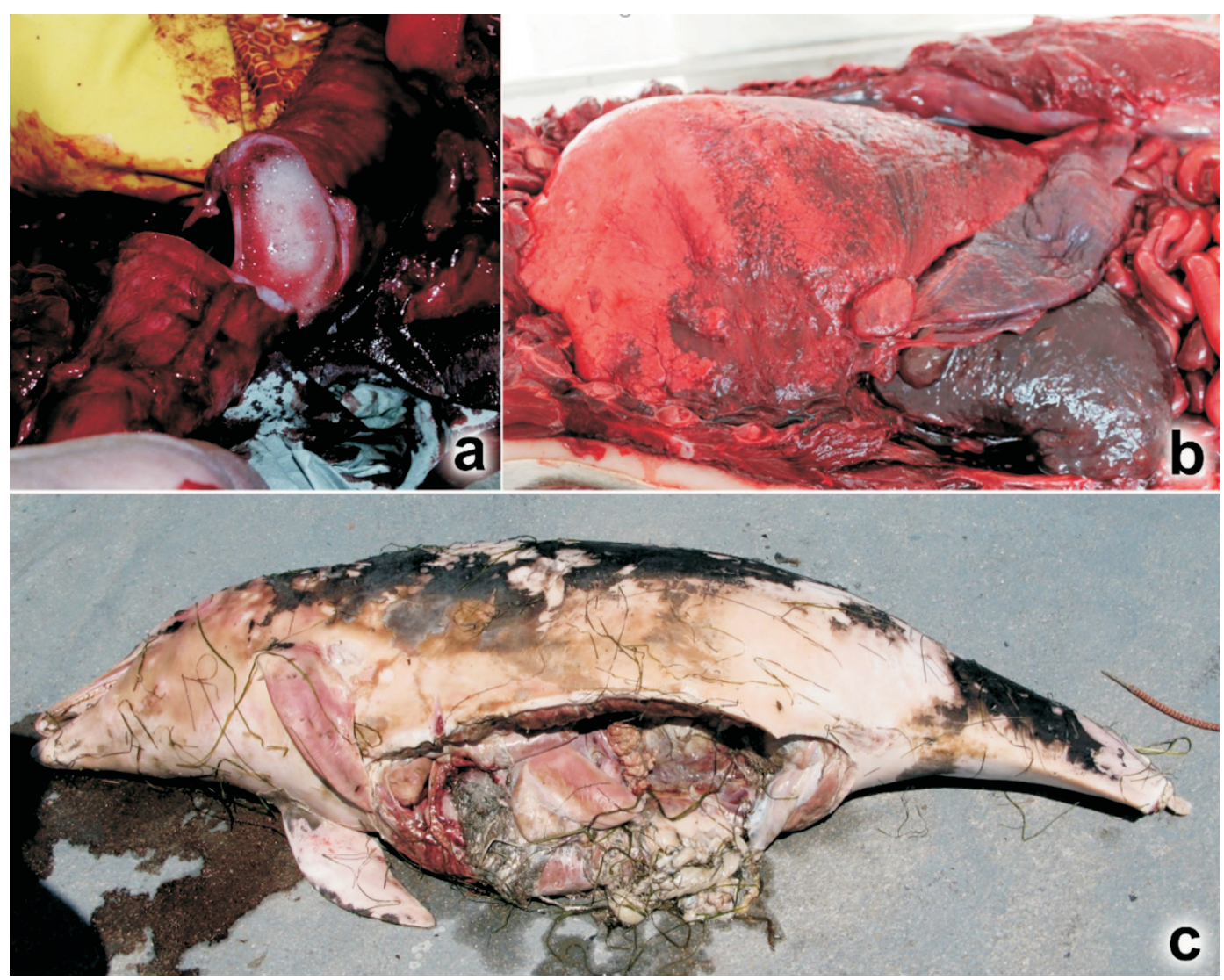

Fig. 3. Bycatch associated lesions: a) persistent froth in the trachea (dolphin ID 103), b) edematous lungs (dolphin ID 395) and c) amputated fluke and penetrating incision into the abdominal cavity (dolphin ID 166). Criteria for the diagnosis of bycatch are modified from KUIKEN (1996) (Table 1).

larynx strangulations, long term tail entanglement and fishing gear in the stomach. They affected 30 bottlenose dolphins, and in some cases multiple fisheries-related findings were observed (Table 3).

Larynx strangulations. Findings of net particles around the larynx were considered larynx strangulations (Fig. 4a and 4b). These conditions were observed in 16 bottlenose dolphins $(5.3 \%$ of examined carcasses, $\mathrm{n}=300)$, of which 15 were adults ( 6 females, 8 males and 1 of unknown sex) and one was a juvenile male. Twelve of these cases were previously reported and described (ĐURAS GOMERČIĆ et al., 2009). In all animals larynx strangulation was determined as the cause of death. It caused tissue damage that ranged from mild mucosal injuries to severe cartilage destruction. We presume that in animals with mild mucosal injuries the strength of the strangulation caused severe breathing disorders or sudden larynx displacement, and immediate death. In cases with chronic laryngeal injuries, the animal presumably died because of chronic breathing disorders, larynx displacement, inflammation processes of the larynx and in some cases aspiratory pneumonia. Among these cases, five animals also accumulated fishing gear in their stomach, and we presume that these animals used depredation from fishing nets as a way of feeding. Besides larynx strangulation and fishing gear in the stomach, one juvenile bottlenose dolphin had a chronic lesion on its tail due to entanglement with a fishing net and rope particles (ID 314, Fig. $5 b)$.

Long-term tail entanglement. Fishing ropes and net particles encircled the tails of three bottlenose dolphins (ID 211 - male adult, ID 314 - male juvenile and ID 355 - female calf) (Fig. 5), including a case of suspected bycatch. They caused severe chronic injuries in the form of deep cuts. 


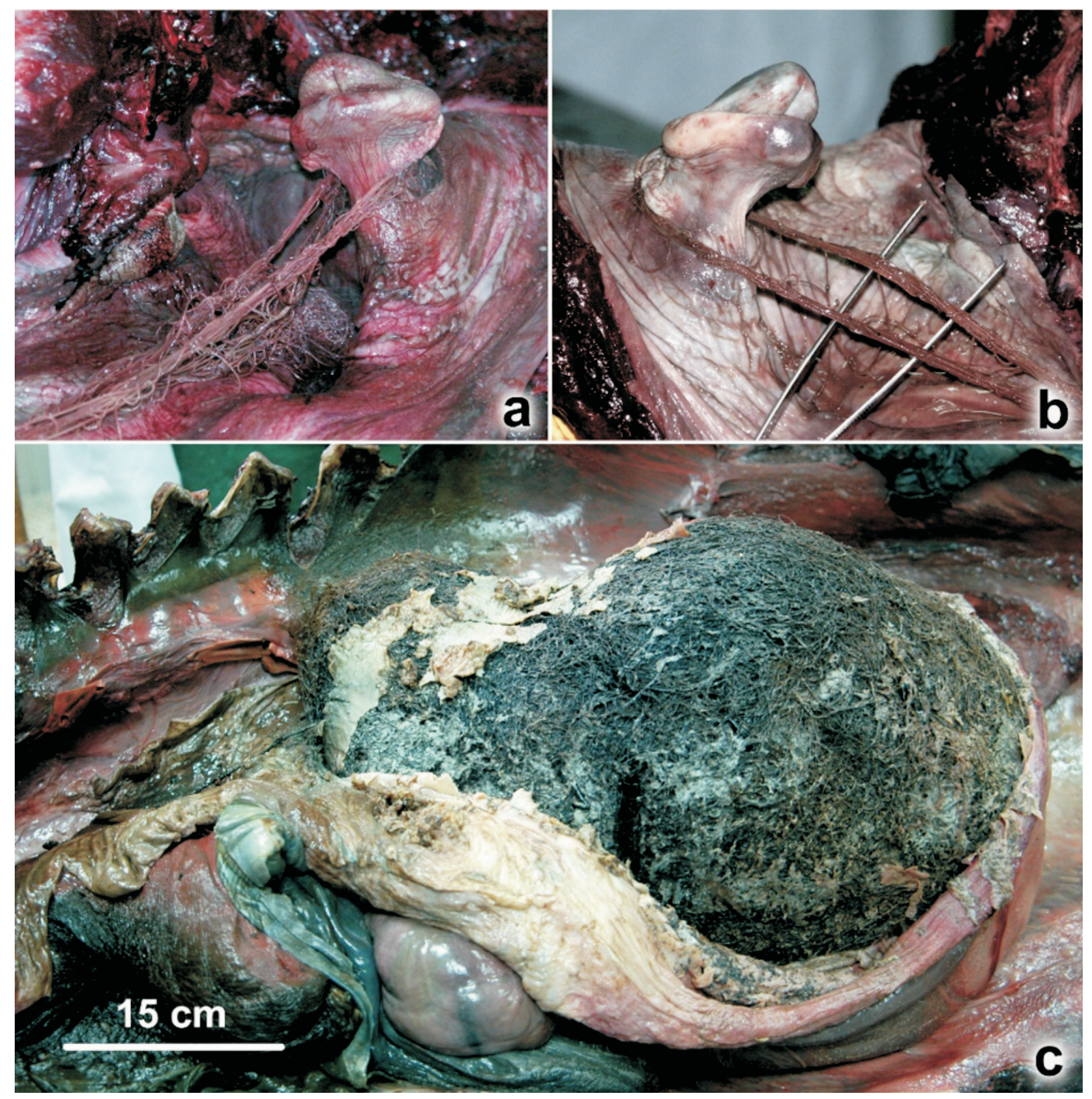

Fig. 4. Cetacean - fisheries interactions other than bycatch in bottlenose dolphins from the Adriatic Sea: larynx strangulation with a net particle a) dolphin ID 102 and b) dolphin ID 112; c) ball of net particles in the stomach of dolphin ID 301 .

Some of these cuts were overgrown by granulomatous tissue suggesting a chronic condition. The dolphin ID 211 (male adult, Fig. 5a) died as suspected bycatch. Prior to death, it accumulated fishing gear in its stomach and had chronic lesions of the tail that were caused by fishing ropes. The juvenile male (ID 314, Fig. 5b) died due to larynx strangulation and had fishing gear in the stomach besides the tail entanglement. The female calf (ID 355, Fig. 5c) was observed alive prior to death. It was floating on the sea surface and was heavily emaciated. Regrettably, it died during a rescue attempt.
Fishing gear in the stomach. Fishing gear in the stomach was found in 22 bottlenose dolphins $(7.3 \%$ of examined carcasses, $n=300$ ). Three of them were categorized as suspected bycatch, 19 cases were categorized as cetacean-fisheries interaction other than bycatch. In six of these 19 cases, larynx strangulation was recorded along with fishing gear in the stomach. The fishing gear was in the form of cotton and nylon net particles, nylon ropes and hooks, and was always found in the first stomach chamber. Twenty-one affected animals were adults, and one was a juvenile, while 13 were females and 

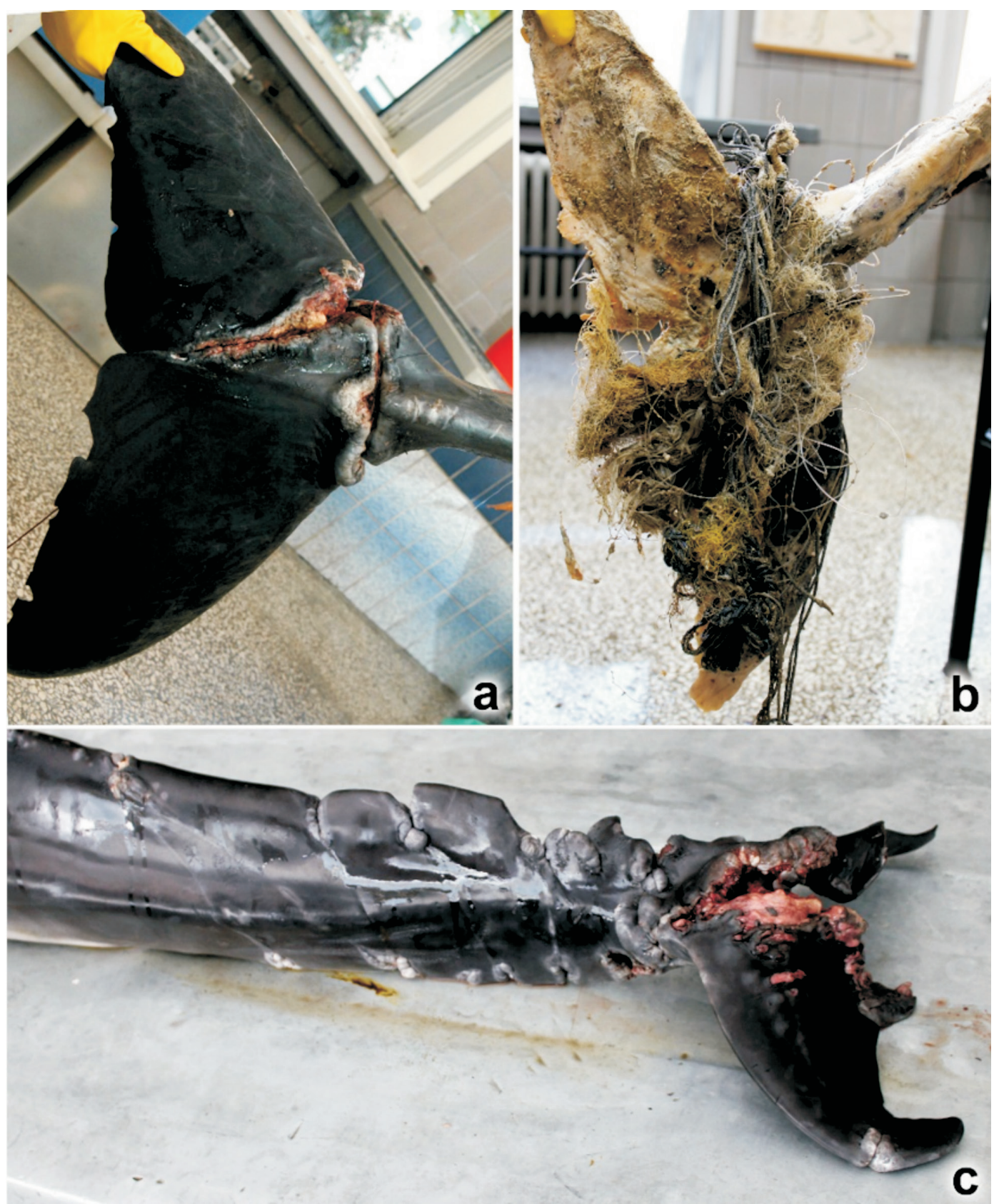

Fig. 5. Fishing gear injuries in the bottlenose dolphins from the Adriatic Sea: entangled fluke with lesions a) dolphin ID 211 and b) dolphin ID 314, c) tail with chronic lesions due to entanglement (dolphin ID 355).

nine were males. The number of net particles in the stomach varied from one to 13 pieces. However, in some cases the number of ingested net particles could not be determined because they formed a firm bundle. An extremely large bundle of net particles was found in the stomach of the bottlenose dolphin ID 301 (Fig. 4c). It was $45 \mathrm{~cm}$ in diameter and had a mass of $9 \mathrm{~kg}$. Fishing hooks were found in the stomachs of seven bottlenose dolphins, while in three of them hooks were found among net particles and fishing ropes.

Ingested marine litter. Marine litter not associated with cetacean-fisheries interactions was found in the stomachs of four examined 


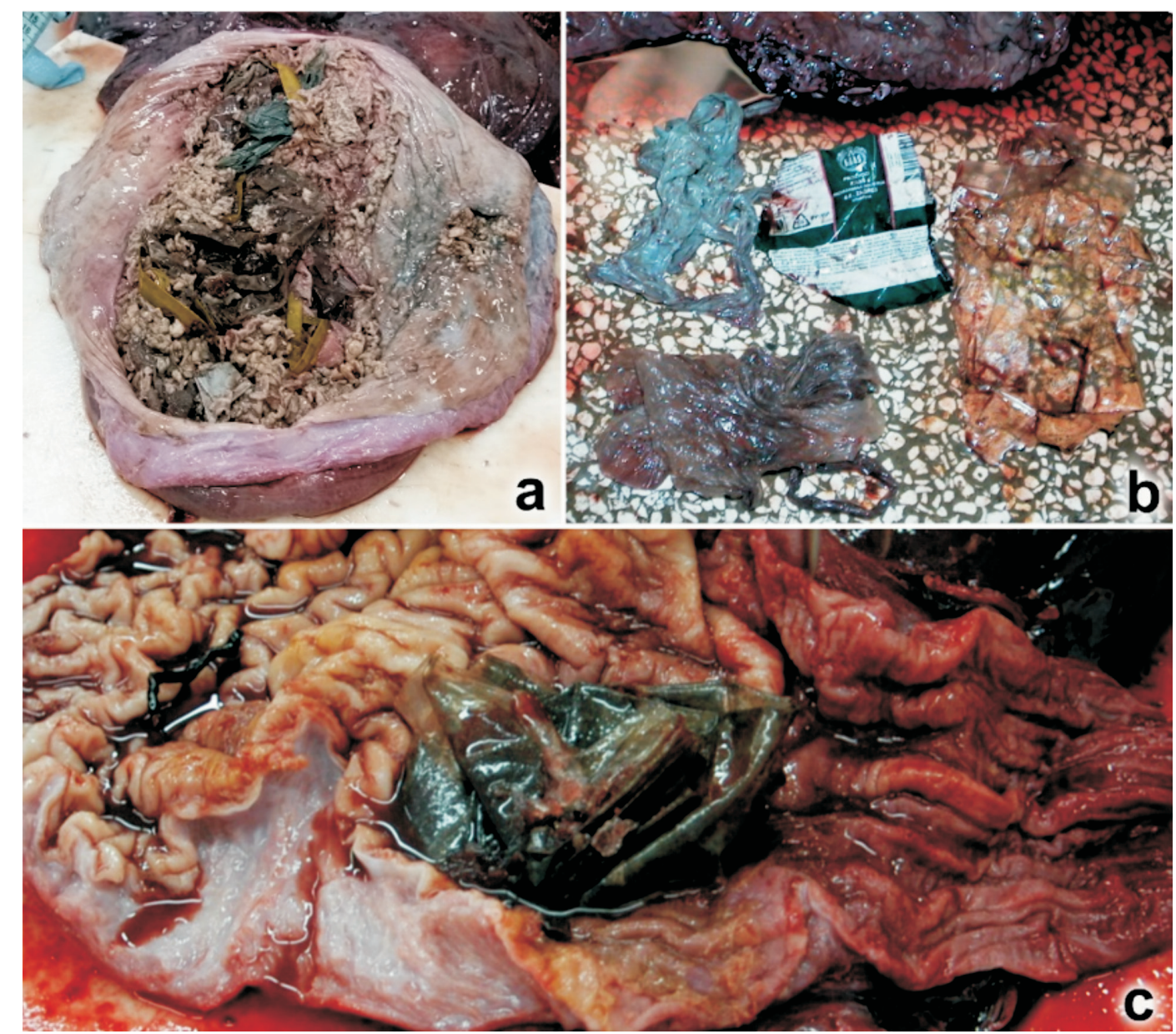

Fig. 6. Plastic wrappings and bags in the stomach of a) bottlenose dolphin ID 391, b) Cuvier's beaked whale ID 58 and c) striped dolphin ID 431.

carcasses $(1.3 \%$ out of 300$)$ : two bottlenose dolphins, a Cuvier's beaked whale and a striped dolphin (Table 2). It was in form of plastic bags, plastic wrappings, and pieces of cloth (Fig. 6). All four cetaceans were extremely emaciated. The bottlenose dolphin ID 76 had three pieces of plastic wrappings and the bottlenose dolphin ID 391 (Fig. 6a) had five plastic wrappings and a piece of cloth in their stomach. The striped dolphin (ID 431, Fig. 6c) had one plastic bag in its stomach, while Cuvier's beaked whale (ID 58, Fig. 6b) had four plastic bags in its stomach, which was previously reported and described (GOMERČIĆ et al., 2006). In three animals the marine litter was found stuck in the openings between the stomach chambers. Obstipation of the gastrointestinal tract was determined as the cause of death in these animals (Cuvier's beaked whale, striped dolphin and bottlenose dolphin ID 391). The bottlenose dolphin ID 76 had fishing gear in addition to marine litter in its stomach, however, the cause of death of this animal was a gun injury, i.e. deliberate killing.

\section{Discussion}

A total of 459 dead cetaceans were recorded along the Croatian part of the Adriatic Sea within the 30 year-long program of cetacean research in Croatia, with 300 of them examined postmortally. This makes an annual mean number of 15.3 cases recorded and 10 examined. Fairly continuous distribution of dead cetacean records, i.e. lack of geographic clustering of bycatch cases, was recorded which indicates the absence of hot spots of cetacean mortality, as well as the absence of any stranding or bycatch hot spots along the Croatian part of the 
Adriatic Sea. Unfortunately, cetacean-fisheries interactions occur frequently in the Croatian part of the Adriatic Sea as its total prevalence is $20.9 \%$ of the recorded or $32 \%$ of the examined carcasses ( 96 cases in total).

The total cetacean bycatch prevalence in the Croatian part of the Adriatic Sea is $14.4 \%$ of the recorded dead cetaceans or $19.7 \%$ of the examined carcasses. The prevalence of bycatch is the highest in the bottlenose dolphin, which is the most common species along the Croatian coast of the Adriatic Sea, although our results show that other species are also vulnerable. As many as $18.3 \%$ of recorded, or even $21.7 \%$ of examined bottlenose dolphins died during the last three decades because of bycatch.

The cetacean bycatch prevalence varies worldwide. Studies showed that $18.4 \%$ (25 out of 136 examined) cetaceans (harbour porpoises Phocoena phocoena, striped dolphins and common dolphins) were stranded as known or suspected bycatch between 1989 and 1993 along the coast of Wales (BAKER, 1996). Between 1990 and 1993 $11.1 \%$ harbour porpoises ( 8 out of 72 examined) died for the same reason on the coast of England (KUIKEN etal., 1996). The rate of cetaceans affected by bycatch from Hong Kong waters was $12.5 \%$ ( 8 out of 64 examined) during the period from 1993 to 1998 (PARSONS and JEFFERSON, 2000). In mass mortalities caused by bycatch in fishery hotspot areas, the reported rate of bycatch is much higher. In a mass mortality reported in UK waters in 1992, $79 \%$ (30 of 38) of the common dolphins examined died due to bycatch, while in two previous years, $47 \%$ (9 of 19 examined animals) showed lesions associated with bycatch in the same area (KUIKEN et al., 1994). In fisheries hotspots, the bycatch rate can be very high, as reported in southwestern UK waters where $61 \%$ cetaceans (253 out of 415 cetaceans) examined between 1990 and 2006 died due to bycatch (LEENEY et al., 2008). Our findings indicate that bycatch prevalence is not as high as in mass mortalities caused by bycatch in fishery hotspot areas, however, it is unfortunately as high as in other studied regions that did not witness mass mortality events, and as such poses a major threat to bottlenose dolphins in the Adriatic Sea. There is no knowledge on how many cetacean carcasses drifted away and were not available for postmortem examination. It is presumed that offshore bycatch may be less detectable, as carcasses are less likely to reach the coast and be documented (LEENEY et al., 2008). Therefore, the bycatch prevalence reported here might be underestimated.

Furthermore, bycatch affects all age groups of bottlenose dolphins. We recorded bycaught calves with maternal milk remains in their stomach, and it seems that these calves were following their depredating mothers into fishing nets where they became entrapped and died. Calf deaths of bottlenose dolphins due to bycatch were previously reported in Brazil (BEZAMAT et al., 2020) and are now confirmed in the Adriatic Sea.

Evidence of recent feeding, i.e. food remains in the stomach that may be undigested or partly digested, is often typical of bycaught animals (KUIKEN et al., 1996; DE QUIRÓS et al., 2018). In our study as many as $86.4 \%$ bycaught specimens showed evidence of recent feeding. KUIKEN et al. (1994) reported evidence of recent feeding in $84 \%$ (32 of 38) common dolphins that died during a mass mortality due to bycatch in UK waters in 1992. Other studies showed even higher numbers: in $97 \%$ (127 of 165) bottlenose dolphins caught in shark nets off the Natal coast, Africa (COCKCROFT and ROSS, 1990) and in 100\% (10 of 10) bycaught harbour porpoises from UK waters (BAKER and MARTIN 1992, cited in KUIKEN et al., 1994) undigested or partly digested food remains in the stomach were reported.

However, bycatch is not the only fishery related mortality observed in the Adriatic Sea. A substantial number of cases were affected by larynx strangulation as a result of fish depredation (described previously by ĐURAS GOMERČIĆ et al., 2009), fishing gear that accumulated in the stomach due to depredation, and finally severe long-term tail and fluke injuries caused by fishing nets and ropes. They all emerge as serious threats that affect the health, reproduction and survival of bottlenose dolphins in the Adriatic Sea.

We presume that fishing nets found around the larynx, in the oesophagus and the stomach were actively torn from the rest of the net during 
depredation and swallowed with the fish that was caught in that part of the net. This might indicate that net particles in dolphin stomachs originate from set fishing nets and not from floating ghost nets. Unfortunately, surgical removal of fishing gear from affected animals does not seem feasible, except for rare fortunate incidents like the one of a Risso's dolphin that was stranded alive in Italy with a large hook in its upper jaw. The hook was removed and the animal was released (ZUCCA et al., 2005).

To date, several measures have been proposed to decrease cetacean bycatch and cetacean-fisheries interactions in general. According to HALL et al. (2000), bycatch reduction programs should be planned as a combination of a reduction of the total fishing effort, which entails temporal or spatial closures of certain fishing areas, and a reduction of bycatch per fishing unit, which includes technical modifications of fishing gear and adjustments to the deployment and retrieval of that gear. It also includes training fishing crews in handling gear and vessel manoeuvring. Management actions are additional measures that should be considered to reduce bycatch, such as limiting individual vessel bycatch, selective licensing with a preference for fishermen with the least bycatch, and labelling responsible fishermen, as well as social action such as customer boycotts of products that are not the result of "dolphin-safe" fishing programs (HALL et al., 2000). Furthermore, new technologies should help to reduce cetacean-fishery interaction, through development of acoustically enhanced fishing net fibres, and improvement of acoustic deterrent devices (ANDERSON et al., 2019). Onboard observers and the mandatory use of acoustic deterrent devices should be implemented according to the European Council (PELTIER et al., 2016). However, these measures might not be applicable for artisanal, small-scale fisheries that dominate in the Croatian part of the Adriatic Sea.

Our study shows that bycatch considerably affects the bottlenose dolphin population in the Croatian part of the Adriatic Sea. However, the effect of bycatch on the viability of this population is hard to estimate due to the lack of data on the population size in the Croatian part of the Adriatic Sea, reproductive rates and mortality. In light of this, we would like to emphasize the important statement made by LEENEY et al. (2008): "Even if current levels of bycatch are considered sustainable in some cetacean species and populations, the ethical issue of the death of hundreds of small cetaceans every year, as a result of fishing activities, is one which needs to be addressed". Regrettably, no conservation measures have yet been implemented to reduce bycatch in the Adriatic Sea. The design of a bycatch reduction plan for the entire Adriatic Sea should be a priority. We propose four measures to be discussed for such a plan: I) prohibition of discard at sea, i.e. fishermen would be obliged to bring all their catch ashore, as described in HALL et al. (2000) and this would be controlled via direct surveillance (on-board observers, cameras, etc.). This measure would allow the comprehensive monitoring of bycatch, and would encourage fishermen to fish more economically, i.e. to avoid fishing areas and manoeuvres with high bycatch rates; II) temporal or spatial closures of certain fishing areas; III) conducting studies on the effectiveness of acoustically enhanced fishing net fibres and acoustic deterrent devices; IV) implementing incentives for fishermen using dolphin safe fishing practices, e.g. lower taxes, visual labelling of fisheries that apply dolphin safe measures and their products, and favourable licencing of such fishermen as stated in HALL et al. (2000).

Ingestion of marine litter not associated with cetacean-fisheries interactions was determined in only four $(1.3 \%)$ of the 300 examined cetaceans. The rate was higher in dolphins from British waters where metal foil and plastic sheets were found in the stomach of $11.1 \%$ ( 2 of 18 ) examined cetaceans, a common dolphin and a striped dolphin (BAKER, 1992). In all four cases from our study, ingested litter consisted of plastic, which supports previous findings that plastic is the most frequent type of marine litter in cetacean stomachs (PUIGLOZANO et al., 2018). In cases reported here, the plastic bags were stuck in the first chamber or/and in the opening between the neighbouring chambers and the animals were emaciated, as was reported for dolphins stranded on the coast of Canary Islands (PUIG-LOZANO et al., 2018). Two of the four affected animals from our study were bottlenose 
dolphins and they make $0.8 \%$ of all examined bottlenose dolphins $(n=253)$. Geographical differences in marine debris abundance and cetacean feeding habits are the main reasons for variable ingestion rates in particular population and species (BAULCH and PERRY, 2014). Our finding of low marine litter ingestion rate is somewhat surprising since high amount of marine litter is estimated to end up in the Adriatic Sea (ARCANGELI et al., 2017). On the other hand, such low rate of ingested marine litter in bottlenose dolphins could be explained by their great ability to distinguish marine litter from prey by using echolocation (KELLOGG, 1959). Additionally, bottlenose dolphins usually make shallow dives, while cetacean species that are more likely to ingest marine litter, are those that deep dive and feed on benthic prey (WALKER and COE, 1990; PUIG-LOZANO et al., 2018).

Although not found very prevalent, ingestion of marine litter other than fishing gear was still documented in our study and proved to be fatal for three out of four affected cases. Therefore, the marine litter problem should be addressed alongside with the development of the dolphin bycatch reduction program. In our opinion, marine litter reduction should be an important part of national programs for the total litter reduction. Litter deposits at the coast and on the islands should be carefully planned, organized, and protected from any kind of factors that could bring the litter into the seas, e.g. strong wind, rain, animals. Sea cleaning actions should be organized and supported at all levels together with educational programs for the public. All the proposed measures for dolphin bycatch and marine litter reduction should be planned and implemented as soon as possible to ensure the conservation of cetaceans in the Adriatic Sea. Finally, the reduction of anthropogenic threats to cetaceans worldwide is our responsibility (NICOL et al., 2020).

In conclusion, our study shows that mortality data, especially when collected as part of long-term research programs, offer a valuable insight into the human induced threats that affect cetaceans in the Croatian part of the Adriatic Sea and emphasizes the importance of sustaining national surveillance programs for gaining scientifically based knowledge important for their further protection.

\section{Acknowledgments}

We wish to thank numerous volunteers and students that assisted in reporting, collecting and postmortem examinations of cetacean carcasses over the years. Our special gratitude goes to Darinka Škrtić, DVM, PhD. This work would not be possible without their contribution. This long-term research was funded by the Ministry of Science and Education of the Republic of Croatia, Croatian Agency for the Environment and Nature and Gesellschaft zur Rettung der Delfine e.V., Germany. Collections were made possible by permits from the Ministry of Environmental Protection and Energy of the Republic of Croatia. We thank two anonymous reviewers for valuable comments on previous version of this paper. This article is dedicated to the memory of Professor Hrvoje Gomerčić. He was a true nature enthusiast devoting his professional career to research and protection of marine mammals in Croatia. He introduced marine mammal research and education program to the Faculty of Veterinary Medicine University of Zagreb thirty years ago and is responsible for the valuable data on marine mammals collected over the years until his demise in 2010. We have proudly continued his work to the present day.

\section{References}

ANDERSON, R., M. HERRERA, A. ILANGAKOON, K. KOYA, M. MOAZZAM, P. MUSTIKA, D. SUTARIA (2019): Cetacean bycatch in Indian Ocean tuna gillnet fisheries. Endanger. Species Res. 41, 39-53.

DOI: $10.3354 /$ esr01008

ARCANGELI, A., I. CAMPANA, D. ANGELETTI, F. ATZORI, M. AZZOLIN, L. CAROSSO, V. DI MICCOLI, A. GIACOLETTI, M. GREGORIETTI, C. LUPERINI, M. PARABOSCHI, G. PELLEGRINO, M. RAMAZIO, G. SARÀ, R. CROSTI (2017): Amount, composition, and spatial distribution of floating macro litter along fixed trans-border transects in the Mediterranean basin. Mar. Pollut. Bull. 129, 545-554.

DOI: 10.1016/j.marpolbul.2017.10.028

BAKER, J. R. (1992): Causes of mortality and parasites and incidental lesions in dolphins and whales from British waters. Vet. Rec. 130, 569-572.

DOI: $10.1136 /$ vr.130.26.569

BAKER, J. R. (1996): By-catches of cetaceans around the coast of Wales. In: Diagnosis of bycatch in cetaceans: proceedings of the second ECS workshop on cetacean pathology, Montpellier, France, 2 March 1994 (Kuiken, T., Ed.), European Cetacean Society Newsletter 26, Special Issue, pp. 35-37.

BAKER, J. R., A. R. MARTIN (1992): Causes of mortality and parasites and incidental lesions in harbour porpoises (Phocoena phocoena) from British waters. Vet. Rec. 130, 554-558.

DOI: $10.1136 /$ vr.130.25.554

BAULCH, S., C. PERRY (2014): Evaluating the impacts of marine debris on cetaceans. Mar. Pollut. Bull. 80, 210-221. DOI: 10.1016/j.marpolbul.2013.12.050 
M. Đuras et al.: Cetacean mortality (fisheries interactions and marine litter ingestion) in the Croatian part of the Adriatic Sea from 1990 to 2019

BEARZI, G., G. NOTARBARTOLO DI SCIARA (1995): A comparison of the present occurrence of bottlenose dolphins, Tursiops truncatus, and common dolphins, Delphinus delphis, in the Kvarneric (northern Adriatic Sea). Annales (Annals for Istrian and Mediterranean Studies) 7, 61-68.

BEARZI, G., G. NOTARBARTOLO DI SCIARA, E. POLITI (1997): Social ecology of bottlenose dolphins in the Kvarnerić (Northern Adriatic Sea). Mar. Mamm. Sci. 13, 650-668.

DOI: $10.1111 / j .1748-7692.1997 . t b 00089 . x$

BEARZI, G., D. HOLCER, G. NOTARBARTOLO DI SCIARA (2004): The role of historical dolphin takes and habitat degradation in shaping the present status of the northern Adriatic cetaceans. Aquatic Conserv: Mar. Freshw. Ecosyst. 14, 363-379.

DOI: $10.1002 /$ aqc. 626

BEZAMAT, C., P. V. CASTILHO, P. C. SIMÕES-LOPES, S. N. INGRAM, F. G. DAURA-JORGE (2020): Reproductive parameters and factors influencing calf survival of bottlenose dolphins that engage in a unique foraging cooperation with fishermen. Mar. Biol. 167, 1-12.

DOI: $10.1007 / \mathrm{s} 00227-019-3611-4$

BIRKUN, A. JR. (1996): Complexities of by-catch diagnosis in Black Sea cetaceans. In: Diagnosis of bycatch in cetaceans: Proceedings of the second ECS workshop on cetacean pathology, Montpellier, France, 2 March 1994 (Kuiken, T., Ed.), European Cetacean Society Newsletter 26, Special Issue, pp. 12-15.

BROWNELL JR, R. L., K. RALLS, W. F. PERRIN (1989): The plight of the „forgotten“ whales. Oceanus 32, 5-13.

BROWNELL, R. J., R. REEVES, A. READ, B. SMITH, P. THOMAS, K. RALLS, M. AMANO, P. BERGGREN, A. CHIT, T. COLLINS, R. CURREY, L. DOLAR, T. GENOV, R. HOBBS, D. KREB, H. MARSH, M. ZHIGANG, W. PERRIN, S. PHAY, L. ROJAS-BRACHO, G. RYAN, K. SHELDEN, E. SLOOTEN, B. TAYLOR, O. VIDAL, W. DING, T. WHITTY, J. WANG (2019): Bycatch in gillnet fisheries threatens Critically Endangered small cetaceans and many others. Endanger. Species Res. 40, 285-296. DOI: $10.3354 /$ esr00994

BRUSINA, S. (1889): Mammals of the Adriatic Sea. Reprinted from the XCV. Book of Activities of the Yugoslav Academy of Sciences and Arts. Dionička tiskara, Zagreb, pp. 79-176 (in Croatian).

COCKCROFT, V. G., G. J. B. ROSS (1990): Food and feeding of the Indian Ocean bottlenose dolphin off Southern Natal, South Africa. In: The Bottlenose Dolphin (Leatherwood, S., R. R. Reeves, Eds.).Academic Press, San Diego,pp. 295-308.

CÓZAR,A., F. ECHEVARRÍA, J. I. GONZÁLEZ-GORDILLO, X. IRIGOIEN, B. ÚBEDA, S. HERNÁNDEZ-LEÓN, A. T. PALMA, S. NAVARRO, J. GARCÍA-de-LOMAS, A. RUIZ, M. L. FERNÁNDEZ-de-PUELLES, C. M. DUARTE (2014): Plastic debris in the open ocean. P. Natl. Acad. Sci. USA. 111, 10239-10244.

DOI: $10.1073 /$ pnas. 1314705111
CÓZAR, A., M. SANZ-MARTÍN, E. MARTÍ, J. I. GONZÁLEZ-GORDILLO, B. UBEDA, J. Á. GÁLVEZ, X. IRIGOIEN, C. M. DUARTE (2015): Plastic accumulation in the Mediterranean Sea. PLoS ONE 10(4): e0121762, $1-12$.

DOI: 10.1371/journal.pone.0121762

CRNKOVIĆ, D. (2001): The dolphin problem. In: Fishery and environmental problems of the Kvarner area. (Arko Piljevac, M., Ed.), Prirodoslovni muzej Rijeka, pp. 52-58 (in Croatian).

DE QUIRÓS, Y. B., M. HARTWICK, D. S. ROTSTEIN, M. M. GARNER, A. BOGOMOLNI, W. GREER, M. E. NIEMEYER, G. EARLY, F. WENZEL, M. MOORE (2018): Discrimination between bycatch and other causes of cetacean and pinniped stranding. Dis. Aquat. Organ. $127,83-95$.

DOI: $10.3354 /$ dao03189

ĐURAS, M., D. DIVAC BRNIĆ, T. GOMERČIĆ, A. GALOV (2014): Craniometry of bottlenose dolphins (Tursiops truncatus) from the Adriatic Sea. Vet. arh. 84, 649-666.

ĐURAS, M., I. JAGAR, T. GOMERČIĆ, A. WATSON, D. ŠKRTIĆ, A. GALOV (2016): Hip bone morphometrics of bottlenose dolphins (Tursiops truncatus) from Adriatic Sea: Sex determination and postnatal development. Mar. Mammal Sci. 32, 945-959.

DOI: $10.1111 / \mathrm{mms} .12305$

ĐURAS GOMERČIĆ, M., A. GALOV, T. GOMERČIĆ, D. ŠKRTIĆ, S. ĆURKOVIĆ, H. LUCIĆ, S. VUKOVIĆ, H. ARBANASIĆ, H. GOMERČIĆ (2009): Bottlenose dolphin (Tursiops truncatus) depredation resulting in larynx strangulation with gill-net parts. Mar. Mammal Sci. 25, 392-401.

DOI: $10.1111 /$ j.1748-7692.2008.00259.x

ESTEBAN, R., P. VERBORGH, P. GAUFFIER, J. GIMÉNEZ, C. GUINET, R. DE STEPHANIS (2016): Dynamics of killer whale, bluefin tuna and human fisheries in the Strait of Gibraltar. Biol. Conserv. 194, 31-38.

DOI: 10.1016/j.biocon.2015.11.031

FAO (2020): The state of Mediterranean and Black Sea Fisheries 2020. General Fisheries Commission for the Mediterranean. Rome, pp. 1-139.

DOI: $10.4060 / \mathrm{cb} 2429$ en

FORTUNA, C. M., C. VALLINI, E. FILIDEI Jr., M. RUFFINO, I. CONSALVO, S. DI MUCCIO, C. GION, U. SCACCO, E. TARULLI, O. GIOVANARDI, A. MAZZOLA (2010): By-catch of cetaceans and other species of conservation concern during pair trawl fishing operations in the Adriatic Sea (Italy). Chem. Ecol. 26, 65-76.

DOI: $10.1080 / 02757541003627662$

GALOV, A., I. KOCIJAN, G. LAUC, M. D. GOMERČIĆ, T. GOMERČIĆ, H. ARBANASIĆ, Z. ŠATOVIĆ, B. ŠEOL, S. VUKOVIĆ, H. GOMERČIĆ (2011): High genetic diversity and possible evidence of a recent bottleneck in Adriatic bottlenose dolphins (Tursiops truncatus). Mamm. Biol. 76, 339-344.

DOI: 10.1016/j.mambio.2010.07.002 
M. Đuras et al.: Cetacean mortality (fisheries interactions and marine litter ingestion) in the Croatian part of the Adriatic Sea from 1990 to 2019

GARCÍA HARTMANN, M., A. S. COUPERUS, M. J. ADDINK (1996): The diagnosis of by-catch: preliminary results of research in the Netherlands. In: Diagnosis of Bycatch in Cetaceans: Proceedings of the Second Ecs Workshop on Cetacean Pathology, Montpellier, France, 2 March 1994 (Kuiken, T., ed.), European Cetacean Society Newsletter 26, Special Issue, pp. 16-26.

GASPARI, S., A. SCHEININ, D. HOLCER, C. FORTUNA, C. NATALI, T. GENOV, A. FRANTZIS, G. CHELAZZI, A. E. MOURA (2015): Drivers of population structure of the bottlenose dolphin (Tursiops truncatus) in the Eastern Mediterranean Sea. Evol. Biol. 42, 177-190.

DOI: $10.1007 / \mathrm{s} 11692-015-9309-8$

GENOV, T., P. KOTNJEK, T. CENTRIH (2020): Occurrence of common dolphins (Delphinus delphis) in the Gulf of Trieste and the northern Adriatic Sea. Aquatic. Conserv. Mar. Freshw. Ecosyst. 1-7.

DOI: $10.1002 /$ aqc. 3407

GOMERČIĆ, H., M. DURAS GOMERČIĆ, T. GOMERČIĆ, H. LUCIĆ, M. DALEBOUT, A. GALOV, D. ŠKRTIĆ, S. ĆURKOVIĆ, S. VUKOVIĆ, D. HUBER (2006): Biological aspects of Cuvier's beaked whale (Ziphius cavirostris) recorded in the Croatian part of the Adriatic Sea. Eur. J. Wildl. Res. 52, 182-187.

DOI: $10.1007 / \mathrm{s} 10344-006-0032-8$

GOMERČIĆ, T., D. HUBER, M. D. GOMERČIĆ, H. GOMERČIĆ (2011): Presence of the Mediterranean monk seal (Monachus monachus) in the Croatian part of the Adriatic Sea. Aquat. Mamm. 37, 243-247.

DOI: 10.1578/AM.37.3.2011.243

HALL, M. A. (1996): On bycatches. Rev. Fish. Biol. Fisher. 6, 319-352.

DOI: $10.1007 / \mathrm{BF} 00122585$

HALL, M. A., D. L. ALVERSON, K. I. METUZALS (2000): By-catch: Problems and solutions. Mar. Pollut. Bull. 41, 204-219.

DOI: 10.1016/S0025-326X(00)00111-9

KELLOGG, W. N. (1959): Auditory perception of submerged objects by porpoises. J. Acoust. Soc. Am. 31, 1-6. DOI: $10.1121 / 1.1907606$

KNIERIEM, A., M. GARCÍA HARTMANN (2001): Comparative histopathology of lungs from by-caught Atlantic white-sided dolphins (Leucopleurus acutus). Aquat. Mamm. 27, 73-81.

KUIKEN, T. (1996): Review of the criteria for the diagnosis of by-catch in cetaceans. In: Diagnosis of Bycatch in Cetaceans: Proceedings of the Second Ecs Workshop on Cetacean Pathology, Montpellier, France, 2 March 1994 (Kuiken, T., Ed.), European Cetacean Society Newsletter 26, Special Issue, pp. 38-43.

KUIKEN, T., M. GARCÍA HARTMANN (1991): Standard protocol for the basic postmortem examination and tissue sampling of small cetaceans. In: Proceedings of the First ECS Workshop on Cetacean Pathology: Dissection Techniques and Tissue Sampling, Leiden, Netherlands, 13 - 14 September 1991 (Kuiken, T., M. García Hartmann,
Eds.), European Cetacean Society Newsletter 17, Special Issue, pp. 26-39.

KUIKEN, T., V. R. SIMPSON, C. R. ALLCHIN, P. M. BENNETT, G. A. CODD, E. A. HARRIS, G. J. HOWES, S. KENNEDY, J. K. KIRKWOOD, R. J. LAW, N. R. MERRETT, S. PHILLIPS (1994): Mass mortality of common dolphins (Delphinus delphis) in south west England due to incidental capture in fishing gear. Vet. Rec. 134, 81-89.

DOI: $10.1136 / v r .134 .4 .81$

KUIKEN, T., M. O'LEARY, J. BAKER, J. KIRKWOOD (1996): Pathology of harbour porpoises (Phocoena phocoena) from the coast of England, suspected of bycatch. In: Diagnosis of Bycatch in Cetaceans: Proceedings of the Second ECS Workshop on Cetacean Pathology, Montpellier, France, 2 March 1994 (Kuiken, T., ed.), European Cetacean Society Newsletter 26, Special Issue, pp. 31-34.

LAIST, D. (1987): Overview of the biological effects of lost and discarded plastic debris in the marine environment. Mar. Pollut. Bull. 18, 319-326.

DOI: 10.1016/S0025-326X(87)80019-X

LAMBERT, C., M. AUTHIER, G. DORÉMUS, S. LARAN, S. PANIGADA, J. SPITZ, O. VAN CANNEYT, V. RIDOUX (2020): Setting the scene for Mediterranean litterscape management: The first basin-scale quantification and mapping of floating marine debris. Environ. Pollut. 263, $1-8$.

DOI: $10.1016 /$ j.envpol.2020.114430

LEENEY, R. H., R. AMIES, A. C. BRODERICK, M. J. WITT, J. LOVERIDGE, J. DOYLE, B. J. GODLEY (2008): Spatio-temporal analysis of cetacean strandings and bycatch in a UK fisheries hotspot. Biodivers. Conserv. 17, 2323-2338.

DOI: $10.1007 / \mathrm{s} 10531-008-9377-5$

MILANI, C. B., A. VELLA, P. VIDORIS, A. CHRISTIDIS, N. KAMIDIS, E. LEYKADITOU (2019): Interactions between fisheries and cetaceans in the Thracian sea (Greece) and management proposals. Fish. Manag. Ecol. 26, 374-388.

DOI: $10.1111 /$ fme. 12370

NICOL, C., L. BEJDER, L. GREEN, C. JOHNSON, L. KEELING, D. NOREN, J. VAN DER HOOP, M. SIMMONDS (2020): Anthropogenic threats to wild cetacean welfare and a tool to inform policy in this area. Front. Vet. Sci. 7, 1-12.

DOI: $10.3389 /$ fvets. 2020.00057

PARSONS, E. C. M., T. A. JEFFERSON (2000): Post-mortem investigations on stranded dolphins and porpoises from Hong Kong waters. J. Wildl. Dis. 36, 342-356.

DOI: 10.7589/0090-3558-36.2.342

PELTIER, H., M. AUTHIER, R. DEAVILLE, W. DABIN, P. D. JEPSON, O. VAN CANNEYT, P. DANIEL, V. RIDOUX (2016): Small cetacean bycatch as estimated 
from stranding schemes: The common dolphin case in the northeast Atlantic. Environ. Sci. Policy 63, 7-18.

DOI: 10.1016/j.envsci.2016.05.004

PUIG-LOZANO, R., Y. BERNALDO de QUIRÓS, J. DÍAZDELGADO, N. GARCÍA-ÁLVAREZ, E. SIERRA, J. De la FUENTE, S. SACCHINI, C. M. SUÁREZ-SANTANA, D. ZUCCA, N. CÂMARA, P. SAAVEDRA, J. ALMUNIA, M. A. RIVERO, A. FERNÁNDEZ, M. ARBELO (2018): Retrospective study of foreign body-associated pathology in stranded cetaceans, Canary Islands (2000-2015). Environ. Pollut. 243, 519-527.

DOI: $10.1016 /$ j.envpol.2018.09.012

RICE, D. W. (1998): Marine mammals of the world: systematics and distribution. Soc. Mar. Mammal. Special publication No. 4, 1-231.

ROCHA, R. C., P. J. CLAPHAM, Y. V. IVASHCHENKO (2014): Emptying the oceans: A summary of industrial Whaling catches in the $20^{\text {th }}$ century. Mar. Fish. Rev. 76, $37-48$

DOI: $10.7755 /$ MFR.76.4.3
SIEBERT, U., H. BENKE, K. FRESE, F. PIRRO, R. LICK (1996): Postmortem examination of by-catches from German fisheries and of suspected by-catches found on the coast of Germany. In: Diagnosis of Bycatch in Cetaceans: Proceedings of the Second ECS Workshop on Cetacean Pathology, Montpellier, France, 2 March 1994 (Kuiken, T., Ed.), European Cetacean Society Newsletter 26, Special Issue, pp. 27-30.

WALKER, W. A., J. M. COE (1990): Survey of marine debris ingestion by odontocete cetaceans. Proceedings of the Second International Conference on Marine Debris, Honolulu, Hawaii, 2-7 April 1989 (Shomura, R. S., M. L. Godfrey, Eds.), U.S. Dep. Commer., NOAA Tech. Memo. NMFS, NOAA-TM-NMFS-SWFSC-154, pp. 2-7.

ZUCCA, P., G. DI GUARDO, M. FRANCESE, D. SCARAVELLI, T. GENOV, A. MAZZATENTA (2005): Causes of stranding in four Risso's dolphins (Grampus griseus) found beached along the North Adriatic Sea coast. Vet. Res. Commun. 29, 261-264.

DOI: $10.1007 / \mathrm{s} 11259-005-0057-6$

Received: 3 August 2020

Accepted: 24 February 2021

ĐURAS, M., A. GALOV, K. KORPES, M. KOLENC, M. BABURIĆ, A. GUDAN KURILJ, T. GOMERČIĆ: Uginuća kitova uzrokovana ribolovom i ingestijom morskog otpada u hrvatskom dijelu Jadranskoga mora tijekom razdoblja od 1990. do 2019. Vet. arhiv 91, 189-206, 2021.

\section{SAŽETAK}

Različiti antropogeni čimbenici negativno utječu na preživljavanje kitova u svim svjetskim morima. U ovom istraživanju prikazujemo utjecaj ribolova i ingestiju morskog otpada na preživljavanje kitova u razdoblju od 1990. do 2019. u hrvatskom dijelu Jadranskoga mora. Analizirani podaci prikupljeni su dugogodišnjim praćenjem stanja morskih sisavaca u ovom području. Ukupan broj nalaza uginulih kitova jest 459 te uključuje 334 dobra dupina (Tursiops truncatus), 40 plavobijela dupina (Stenella coeruleoalba), deset glavatih dupina (Grampus griseus), šest krupnozubih dupina (Ziphius cavirostris) i četiri velika sjeverna kita (Balaenoptera physalus). Tristo jedinki postmortalno je pregledano. Interakcije kitova i ribolova učestale su u Jadranskome moru s obzirom na to da su utvrđene u 20,9 \% uginulih kitova. Ukupan broj dupina stradalih kao slučajan ulov jest 66 (14,4 \% svih nalaza). Osrednje gojno stanje i neprobavljeni/poluprobavljeni plijen u želucu najučestaliji su nalazi u dupina stradalih kao slučajan ulov. Od ostalih nalaza ističu se pjena u dišnim putevima, edematozna pluća, podljevi te odrezana repna peraja ili cijeli rep. Interakcije kitova i ribolova koje se ne smatraju slučajnim ulovom opisane su u 30 jedinki i uključuju strangulaciju grkljana, dugotrajan zapletaj repa i ribolovni alat u želucu. Ingestija morskog otpada utvrđena je u četiri jedinke. Ovo istraživanje potvrđuje negativan antropogeni utjecaj na kitove u Jadranskome moru, osobito na dobrog dupina, te upućuje na potrebu hitnog razvoja mjera za smanjenje broja dupina stradalih kao slučajan ulov. Ono također ističe važnost nacionalnih protokola za praćenje kitova kao izvora znanstvenih podataka potrebnih za predlaganje i provedbu mjera zaštite koje će povećati izglede za njihovo dugoročno preživljavanje.

Ključne riječi: slučajni ulov; zapletanje u mrežu; ribolovni alati; morski otpad; kitovi; Jadransko more 